\title{
The Prohibition of Genocide as an International Norm of jus cogens and its Implications for International Law
}

\author{
Arsalan Haji AlMizory
}

College of Law and Politics, Department of Law, Nawroz University, Kurdistan Region - Iraq

\begin{abstract}
The crime of Genocide is considered as one of the most severe crimes against humanity. The international legal definition of the crime of genocide is found in Article (II) and (III) of the 1948 Convention on the Prevention and Punishment the Genocide. However, the Convention failed to cover many of the major human rights violations and mass killings committed by perpetrators and their accomplices. This article focuses on the interpreting the definition of genocide, and addressing the problems involved in both the prosecution and defence of charges of genocide when committed by individuals. It will argue that not every act committed with intention to destroy, in whole or in part, a protected group will lead to a rise in the responsibility for genocide. Only those, which are mentioned in Article (II) of the Genocide Convention, may form the intent (Actus Reus) of genocide. Rather, it will analyse how the Genocide Convention allows the establishment of Universality Jurisdiction against the crime of genocide by prescribing that genocide is a crime under international law, and how the States can exercise Universal Jurisdiction over acts committed outside a State's territory by a foreigner.
\end{abstract}

KEYWORDS : Genocide, Genocide Convention, Crimes Against Humanity, ICC, ICTY, ICTR and Universality Jurisdiction.

\section{INTRODUCTION}

Genocide, which was punished at Nuremberg as part of the wider notion of crimes against humanity in the form of persecution or extermination, took a different route; its international prohibition was solemnly incorporated in the 1948 Genocide Convention (Cassese, 2009). The term of "genocide" was coined by Raphael Lemkin in 1943. The discriminatory laws and mass-scale persecution of Jews and other groups at that time led to the description and conceptualization this new word, to denote and old practice in its modern development (Boot, 2002). Article 6 (c) of the Charter of the International Military Tribunal (IMT) did not envisage genocide as a crime falling under the Tribunal's jurisdiction. However, in referring to

Academic Journal of Nawroz University

(AJNU) Volume 7, No 3 (2018).

Received 1 March 2018;

Regular research paper : Published 20 June 2018

Corresponding author's e-mail : arsalanissa@gmail.com

Copyright (C2018 Arsalan Haji AlMizory.

This is an open access article distributed under the

Creative Commons Attribution License. crimes against humanity it used wording (murder, extermination, enslavement, deportation, and other inhuman acts committed against any civilian population, and persecution on political, racial or religious grounds) that encompassed large-scale massacres of ethnic, racial or religious groups (Cassese, 2008). Genocide considered as a specific crime in 1948, when the UN General Assembly adopted the Genocide Convention. Hence, the prohibition of genocide is closely related to the right to life, one of the fundamental human rights defined in international declarations and conventions (Schabas, 2000). The Convention definition of genocide has seemed too restrictive, and narrow. It has failed to cover, in a clear and unambiguous manner, many of the major human rights violations and mass killings perpetrated by dictators and their accomplices (Schabas, 2009). Furthermore, the convention has flaws or omissions, the most serious being, the convention confines itself to the physical destruction of groups to which persons normally belong involuntarily and often, by birth. Thus the definition of genocide does not embrace cultural genocide, that is the destruction of the language and cultural of a group, or extermination of a group on political ground, further, the four classes of 
protected groups specified in Article (II) (national, ethnical, racial, or religious groups) are not defined (Evans, 2008). Further problems in the legal definition of genocide, would have usually open the question whether the aim must be the destruction of the group in the whole or in part as such, so that proving the intent of genocide, a wider plan would be problematic issue as well. Thus, as Schabas pointed out, the focus is on the interpreting the definition and addressing the problems involved in both the prosecution and defence of charges of genocide when committed by individuals.

\section{Background}

Although the crime of genocide is associated with Hitler's Final Solution, which was not the first campaign of extermination that would qualify as genocide," the systematic extermination of Armenians by the Young Turks beginning in April 1915 an episode that loomed large in Lemkin's early thinking about the need to criminalize what he later termed genocide was the first genocide in the twentieth century" (Orentlecher, 2009). Genocide has been described as the ultimate crime. Although the Armenian massacre of 1915 did not result in any serious criminal proceedings, revulsion caused by Jewish Holocaust eventually led to the adaption in 1948 of the Genocide Convention (Bantekas and Nash, 2007). The new world order that emerged in the aftermath of the First World War, and that to some extent was reflected in the 1919 peace treaties manifested a growing role for the international of human rights. Two aspects of the post-war regime are of particular relevance to the study of genocide. First, the need for special protection of national minorities was recognized, this took the form of a web of treaties, bilateral and multilateral, as well as unilateral declaration. Secondly, the world also saw the first attempt to establish an International Criminal Court, accompanied by the suggestion that massacre of ethnic minorities within a State's own border might give rise to both state and individual responsibility (Schabas, 2000). It is clear that, as an international crime, the identification of genocide came as a response to the Holocaust. The term genocide was not coined in a twentieth century as Massacre with the intent to destroy national or ethnic minorities until 1944 by Raphael Lemkin, a Polish lawyer. The indictment of the defendants at Nuremburg accused them of having conducted deliberate and systematic genocide, the extermination of racial and national groups, against the civilian population of certain occupied territories in order to destroy particular races and classes of people, and national, racial or religious groups, particularly Jews, Poles, and Gypsies (Cryer, Friman, Robinson and Wilmshurst, 2007). However, the term was not mentioned in Nuremberg Tribunal as a crime. Many years later the International Criminal Tribunal for Rwanda (ICTR) said : the crimes prosecuted by the Nuremberg Tribunal, namely the Holocaust of the
Jews or the "Final Solution", were very much constitutive of genocide, but they could not be defined as such because the crime of genocide was not defined until later (Ibid, p : 166). Genocide was not recognized explicitly as a separate international crime until the adaption of General Assembly resolution 96(1) of 11 December 1946. As a crime of individuals began to be punished, genocide appeared after following the establishment of the International Criminal Tribunal for Yugoslavia (ICTY) and the ICTR. Genocide having been provided for in the Statutes of both Tribunals as well as the ICC (following by provisions relating to the Special Panels for East Timor and the Extraordinary Chambers for Cambodia), the first two courts have had the opportunity to try quite a few persons accused of this crime, they have delivered important judgments on the matter (Cassese, 2008). Thus, after the establishment of the ICTY and the ICTR, some national courts began to pronounce on some cases of genocide and follow criminal proceeding against persons accused of committed most serious crimes. Such as German courts on some cases of genocide, and the national courts in former Yugoslavia.

\section{The International legal definition of Genocide}

Genocide is considered as one of the most severe crimes against humanity. The international legal definition of the crime of genocide is found in Article (II) and (III) of the 1948 Convention on the prevention and punishment the genocide. Article (II) described two elements of the crime of genocide :

1) the mental element, meaning the "intent to destroy, in whole or in part, a national, ethnical, racial or religious group, as such", and

2) the physical element which includes five acts described in sections $a, b, c, d$ and e. A crime must include both elements to be called "genocide."

Article III described five punishable forms of the crime of genocide : genocide; conspiracy, incitement, attempt and complicity (Prevent Genocide International, 2004). During its first session on 11 December 1946, the General Assembly unanimously adopted Resolution 96(I) on the crime of genocide : it declared that :

(Genocide is a denial of the right of existence of entire human groups, as homicide is the denial of the right to live of individual human beings; such denial of the right of existence shocks the conscience of mankind, results in great losses to humanity in the form of cultural and other contributions represented by this human groups, and is contrary to moral law and to the spirit and aims of the United Nations), (Boot, 2002). The legal definition of the crime of genocide as included also in the Rome Statute in Article 6 which provides :

For the purpose of this Statute, genocide means any of the following acts committed with the intent to destroy, in whole or in part, a national, ethnical, racial or religious group, such as, Killing members of the group; Causing 
serious bodily or mental harm to members of the group; Deliberately inflicting on the group conditions of life calculated to bring about its physical destruction in whole or in part; Imposing measures intended to prevent births within the group; Forcibly transferring children of the group to another group.

The above key elements of the legal definition of genocide codification were added, unchanged, to the Statute of the ICTY, the ICTR, and the Special Panels of East Timor. Further from its inception the crime of genocide was considered to be a species of a crime against humanity, it has since been accepted, in general formulation, but also in the specific form given to it by the Convention, as part of customary international law (Zahar and Sluiter, 2008). Thus, genocide is a crime under international law even if it is not a crime in some countries, and the incitement to commit genocide is also a crime under international law.

III.Genocide and the relationship to Crime Against Humanity

It can be argued that, genocide has similarities to crime against humanity. The genocide Convention makes clear in Article (I) that genocide can be committed" in time of peace as in war and now that is no longer a nexus between crimes against humanity and conflict, it is even clear that genocide can be, indeed typically is, a form of crimes against humanity" (Cryer, Friman, Robinson and Wilmshurst, 2007). However, the difference appears in the objective and subjective elements of the two crimes in many respects. As for the objective elements as Cassese pointed out, the two crimes may undoubtedly overlap to some extent : such as, killing members of an ethnic or religious group may such as fall under both categories; the same holds true for causing serious bodily or mental harm to members of a racial or religious group, or even for the other classes of protected group. In addition, the relationship between the two might be compared with that of murder and manslaughter in ordinary criminal law, "every intentional murder is also a homicide, but the reverse cannot be said, the category of crimes against humanity covers an immensely broader spectrum of atrocities than genocide, which is limited to the destruction of national, ethnic, racial and religious groups" (Schabas, 2009). So that, unlike crime against humanity, genocide does not obviously include any objective requirement of scale. The two crimes of their objective elements are normally "reciprocally special, in that they form overlapping circles which nevertheless intersect only tangentially" (Cassese, 2008).

The main difference between the two categories is from the perspective of the "mens rea" the special intent, the two categorise do not overlap at all. In the case of genocide, international law requires the special intent to destroy, in whole or in part, a particular group, further to the intent to commit the underlying offence. While in the case of crime against humanity, international law required the intent to commit the underlying offence plus knowledge of the widespread or systematic practice constituting the general context of the offence (Ibid : $p$ : 145). Rather the interests protected by the law against genocide are narrower than for crimes against humanity, whilst the law against genocide protects the rights of certain groups to survival, and thus human diversity (Cryer, Friman, Robinson and Wilmshurst, 2007). Thus the marked of the gravity of genocide is not by an objective element but by the subjective Special intent, the intent to destroy a national, ethnic, racial or religious group as such. Rather genocide Convention introduced minimum requirements concerning the prosecution of those who committed the genocide as it is described in the Convention, the definition of 'genocide' in the 1948 Convention is given only for the purposes of the Convention and does not precludes evolution of this notion in international law, while the Crimes Against Humanity and War Crimes Act (2000), "providing for the implementation of the Rome Statute of the International Criminal Court respecting genocide, crimes against humanity and war crimes in the United Kingdom, describes for the purposes of the act separately 'crime against humanity; genocide and "war crime" (Satkauskas, 2004). Finally, It is argued that, as far as legal consequences are concerned, it's no longer has any importance, the International Criminal Court may prosecute both genocide and crimes against humanity, the most severe sentence of life imprisonment may be imposed for either crime (Schabas, 2009).

IV.In what problems remains the International legal definition of Genocide?

It can be argued that, not every act committed with intention to destroy, in whole or in part, a protected group under Genocide Convention will lead to a rise in the responsibility for genocide. Only those which are mentioned in Article (II) of the Genocide Convention may form the intent (actus reus) of genocide. Article 2 (2) a to 2 (2) e of the first provision shown the (actus reus) of genocide precisely its constituent offences and feature, which is the "intent to destroy, in whole or in part, a national, ethnical, racial or religious group, as such. Indeed this high specific meaning and requirements creates a difficulty when the ICC facing to prosecute who is responsible for genocide. The Trial Chamber in Krstic incorporated it, however, requiring that acts of genocide must be committed in the context of manifest pattern of similar conduct, or themselves constitute a conduct that could in itself effect the destruction of the group, in whole or in part (Cryer, Friman, Robinson and Wilmshurst, 2007). The ICC judges will give consideration to the contextual in the elements and guided by it, unless they are convinced that it is inconsistent with the Statute (Ibid. P : 178). So that, many 
experts have considered the definition of genocide as too narrow, since the treaty's adaption none of the mass killing would be covered by it.

\section{Genocide and Universality Jurisdiction}

It has been argued that universal jurisdiction was admitted in the Genocide Convention. The opinion expressed by judge Lauterpachet in a case at the International Court of Justice (ICJ). Judge Lauterpachet interprets that Article (1) of the Genocide Convention allows the establishment of universality jurisdiction against the crime of genocide by prescribing that genocide is a crime under international law, he expressly observes that States can exercise universal jurisdiction over acts committed outside a State's territory by a foreigner (Inazumi, 2005). However, according to Article 1 which reaffirm that genocide is a crime under international law, the State member realize that the law applies irrespective of whether the crime is committed in a time of peace or war. The wording of that provision does not obviously mention universal jurisdiction. Universal jurisdiction to pursue and punish genocide stems primarily from jus cogens, The Eichmann prosecution is paradigmatic of a jus cogens crime commentators are unanimous that "whatever may be the proper scope of jus cogens also known as peremptory norms, genocide falls within it, the principles do not limit universal jurisdiction to jus cogens international crimes, but take a possible more flexible approach to serious crimes under international law" (Macedo, 2004). The principle of universal jurisdiction is classically defined as a legal principle allowing or requiring a state to bring criminal proceeding in respect to certain crimes irrespective of the location of the crime and the nationality of the perpetrator or the victim (Randall, 1998). This principle is said to derogate from the ordinary rules of criminal jurisdiction requiring a territorial or personal link with the crime, the perpetrator or the victim, universal jurisdiction allows for the trial of international crimes committed by anybody, anywhere in the world (Philippe, 2006). Although article VI of the Genocide Convention expressly mentions that "Person charged with genocide shall be tried by a competent tribunal of the State in the territory of which the act was committed, or by such international penal tribunal as may have jurisdiction with respect to those contracting Parties which shall have accepted its jurisdiction", but these jurisdictions are not exclusive, and the Article only "obliges the contracting parties to institute and exercise territorial criminal jurisdiction; while it certainly does not prohibit States, with respect to genocide, from conferring jurisdiction on their criminal courts based on criteria other than where the crime was committed which are compatible with international law, in particular the nationality of the accused, it does not oblige them to do so" (Grief, 2009). In the other words, the genocide is not subject to the universality principle under conventional law; universal jurisdiction may be applied to the crime under customary international law (Bassiouni, 1999). In its 8 April 1993, The international Court of Justice in (Genocide Convention Case, Provisional Measures), declared that, "all parties have assumed the obligation to prevent and to punish the crime of genocide", and "the rights and obligations established by the 1948 Convention are rights and obligations "erga omnes," the ICTY Appeals Chamber declared in the Blaskic case that the obligation for each national jurisdiction "to judge or to extradite the persons presumed responsible for grave violations of international humanitarian law" was customary in character (Walleyn, 2003). It can be argued that, the major problems with undertaking prosecution on the basis of universal jurisdiction is that the "existence of jurisdiction "per se" does not give rise to any obligations on behalf of the territorial or nationality State to assist in any investigation, provide evidence or extradite suspect, further it's also possible problem of forum shopping in which victims or NGOs may seek to initiate prosecution in multiple fora, to maximize the possibility of convection" (Cryer, Friman, Robinson and Wilmshurst, 2007). On the other hand, Immunities and pardons granted at national level as Philippe pointed out, although banned for perpetrators of international crimes owing to the very nature of those crimes, still raise questions regarding the principle of complementarity, Whereas a general amnesty can never be an obstacle to trials of perpetrators of international crimes before the ICC, there are a number of intermediate situations where these issues will in practice weaken the principle of complementarity. The immunity excluded of the 1948 Genocide Convention in Art VI, but the Court as Walleyn mentioned "takes into consideration that art.VI of the same convention provides only for prosecution before national courts of the state on which territory the crimes were committed, and before an international criminal court, and does not provide for prosecution before national courts judging on the basis of universal jurisdiction". In Abbas Hijazi case $v$ Sharon, both Sharon and the State of Israel intervened in the proceedings. It may be noted that Israel has a genocide law that excludes immunity based on official capacity and provides for universal jurisdiction, the "Chamber de mises en accusation in Brussels declared the proceedings inadmissible because the defendant was not present as required by Chamber de mises en accusation article 12, the court pointed out, that the exercise of universal jurisdiction in absentia is contrary to the genocide convention, the Geneva Conventions, the European Convention for the protection of fundamental rights and freedoms, and the principle of sovereign equality of States" (Reydams, 2003). The lack of precise definitions of elements of international crimes, and the conditions of 
the implementation of the principle of complimentarily, and the lack of genuine national prosecution and investigation, may seem a rather problems and disagreement on the principle of complementarity between the national legal system and international law. VI.How to identify the protected groups

It is clear that the major problems concerning the objective element of genocide relate to the notion of the group victim of the crime as well as the identification of the four groups enumerated in the Convention (national, ethnical, racial, and religious) (Cassese, 2008). If the offender views the group as being national, racial, ethnic, or religious, then that should suffice, they contend. In "Kay and Ruzindana", a trial chamber of the International Criminal Tribunal for Rwanda adopted a purely subjective approach noting that an ethnic group could be a group identified as such by others, including perpetrators of the crimes (Schabas, 2009). Equally, the problematic issue is the omission of political groups from the UN definition. The killing of some 500,000 Indonesian communists in 1965-1966; the murder of members of the "Awami League" in 1970-1971 during the breakaway of Bangladesh; the planned annihilation by the Khmer Rouge from 1975 to 1978 of opposition politicians in Kampuchea these were only a few of the political groups whose destruction merited Study (Chalk, 1989). Further, David Hawk mentioned that, the absence of "political groups" from the coverage of the Genocide Convention has unfortunately had the effect of diverting discussion from what to do to deter or remedy a concrete situation of mass killings into a debilitating, confusing debate over the question of whether a situation is legally genocide. Similarly, Schabas pointed out that, the problem with including political groups "is the difficulty in proving a rational basis for such a measure, if political groups are to be included, why not the disabled or other groups based on arbitrary criteria? Accordingly, the definition ought to be expanded to cover all episodes of mass killing.

Nevertheless, the problem of who (or what) is the group obviously starts with "Akayesu" Trial Camber. The Camber turned to the specifics of the indictment, "which alleged that the victims belonged to one of the four groups without specifying which one, the court seemed intent on an ethnic categorization, it said while the Tutsi population did not have culture distinct from the rest of the population, government issued identity cards identified their holders as belonging to one of three ethnics" (Zahar and Sluiter, 2008). Consequently, it comes as a surprise when three-quarters of the way through the Akayesu judgment a new theory is put forth, as if by an invited guest, proposing in effect that the "Tutsi were not one of the four groups explicitly protected by the Convention, but were nevertheless protected because the Tutsi group shared the essence, as it were, of the four listed types of group" (Ibid). Thus, it would seem that in Akayesu Trial the question whether or not a multitude of persons made up a group protected by the rules against genocide was primarily a question of fact. "The court had to establish weather (I) those persons were in fact treated as belonging to one of those protected groups; and (II) they considered themselves as belonging to one of such groups" (Cassese, 2008). Moreover, the Chamber notes that for the purpose of applying the genocide convention, membership of a group is, in essence, a subjective rather than an objective concept. The ICC in "Darfur" case suggests that these subjective perceptions of ethnic difference are definitive; difficulties arise since the definition of genocide does not protect tribes and since the perpetrators and victims in Darfur are in many respects difficult to distinguish in terms of objective identities (Darfur report, paras. 496497). Furthermore, religion is excluding in the Genocide Convention, but at the time, the UN planned a companion instrument on religious discrimination, however as Schabas pointed out that, discrimination on the basic of political opinion, or belonging to a political group, was not included. The Darfur Commission in 2004 found that the people who had been the object of attack did not appear to make up ethnic groups distinct from those to which their attackers belonged; they had same religion, and the same language (Cryer, Friman, Robinson and Wilmshurst, 2007). Meanwhile, the group must have some form of objective existence in the first place; otherwise the Convention could be used to protected entirely fictitious national, ethnic, racial or religious groups (Ibid, p : 173). Thus, the question that arises is whether it would be impossible to punish the physical destruction of a group as such under the genocide convention, if the said group, although stable and membership is by birth, does not meet the definition of any one of the four groups expressly protected? It is argued that the Chamber, it is particular important to respect the intention of the drafters of the Genocide Convention, which according to the travaux preparatoires, was patently to ensure the protection of any stable and permanent group (Zahar and Sluiter, 2008). In addition, genocide can be committed against a group existing only in the mind of the perpetrator an indefensible notion, or is committed when individuals who are not members of that group are eliminated in mistaken belief that they are members of that group equally indefensible. On the other hand, the actus reus of genocide requires the perpetration of act that aim to destroy a group in whole or in part as such. The in part element as the ICTY in"Prosecution v Krestic" pointed out, does not characterise the destruction of the group, but refers instead to the intend of the perpetrator in destroying the group within the confines of a limited geographical area. The Trial Chamber in the Jelistic case 
argued "what proportion of the group is marked for destruction, and beyond what threshold could the crime be qualified as genocide? In particular, the Trial Chamber will have to verify whether genocide may be committed within a "restricted geographical zone", the prosecutor had contended that the zone within which acts to eliminate a group are performed, or intended, may be limited to the size of a region within a country or a municipality "(Zahar, 2001). The decision has been criticized as having set too low a threshold for the scale of genocide, the killing were of 7,000-8,000 men, and it therefore appeared that the people targeted formed a part of a part of a group (Cryer, Friman, Robinson and Wilmshurst, 2007). In contrast, the Trial Camber in "Sikirica Case" argued that, "the intent to destroy a multitude of persons belonging to a group may amount to genocide, even where these persons constitute only part of a group within a given geographical area, a country or a region or a single community (Jorgensen, 2002).

\section{Proving the intent of Genocide}

It has been argued that, since genocide is the gravest crime against humanity, the part targeted must be a substantial part of the group, in term victim numbers, "ICTY and ICTR jurisprudence suggest that the intent to destroy a part of the group must effect a considerable number of individuals that make up a substantial part of that group, in such cases the prosecutor must prove both the intent to destroy the targeted group in the particular area, as well as the intent to destroy substantial part of that group" (Bantekas and Nash, 2007). It is true that, intent is normally proven as a deduction from the material act. Meanwhile, where the genocide involves the destruction of a large number of members of a group," the logical deduction will be more obvious, while if there are only a few victims, this deduction will be far less evidence, even if the criminal is in fact animated with the intend to destroy the entire group". Relying on the quantity of the victims as evidence of genocidal intent, the prosecution will be required to introduce other elements of proof (Schabas, 2000). On the other hand, the term in whole or part do is undermining pleas from criminals, they did not intend the destruction of the group as a whole, for example, the Turkish Government targeted Armenians within its borders, not those of the Diaspora. In Rwanda, extremists do not appear to have given serious consideration to eliminating Tutsi populations beyond the country's borders. Thus, in can be concluded that, in part requires the intention to destroy considerable number of individuals who are part of the group. The special intend required for genocide, its inferred from the defendant's conduct. The intent may be found in what the defendant is alleged to have said at the relevant time, or in the number and category of the defendant's victims (Zahar, 2001). Looking at the definition of genocide, the term intent to destroy nowhere is mentioned an additional adjective, but it characterizing in the narrow sense, and properly need interpretation. Accordingly, to interpret "intent to destroy" to mean specific or special intent would not only go beyond the wording, but would introduce a concept not precisely defined and generally accepted in Common Law countries (Triffterer, 2001). It is true that, the specific intent requirement of article (II) applies to acts committed in time of peace as well as in armed conflict, in the course of armed conflicts, "acts committed without the specific intent will not be sufficient to constitute genocide as defined by the convention" (Schabas, 2000). In addition, in Akayesu decision, the ICTR concluded that, while the principle offender must possess the special or specific intent of genocide, this "is not necessary in the case of accomplices, the Tribunal reduced this to question of whether the accomplice had knowledge of the principle offender's intent, the accused would be an accomplice to genocide, even though he did not share the murderer's intent to destroy the group" (Ibid, p : 221). On the other hand, The Trial Chamber in "Jelisic case" acquitted the accused of genocide, considering that the Prosecutor had failed to prove beyond a reasonable doubt that Jelisic acted with the required intent to destroy in whole or in part a national, ethnic or religious group (The Prosecutor v. Goran Jelisic). Thus, The Chamber argued that the accused must have committed his crimes as part of a wider plan to destroy the group as such, "No source was cited for this interpretation, the Chamber seems to have been influenced by the strong family resem-balance between genocide and persecution as a crime against humanity, and the fact that the latter requires proof of a widespread or systematic attack against civilian "(Zahar, 2001). Thus, genocide is more likely to be committed where the principle offender the actual murderer lacks genocidal intent, but incited or directed to commit the crime by a superior -technically an accomplice who possesses the genocidal intent (Schabas, 2000). Eventually, the interpretation of the special intent element has been criticized. It is said that simple foot soldiers will normally follow orders without necessarily having intent to destroy a whole group, and that it would not be realistic to look for intent from one individual to destroy the group through his own conduct (Wilt, 2006). Further, in relation to an accused who participated in a genocidal campaign, courts may therefore face the difficult choice between acquittals for lack of evidence of the special intent as normally defined and "squeezing ambiguous fact patterns into the specific intent paradigm" (Cryer, Friman, Robinson and Wilmshurst, 2007). In addition, in "Prosecutor v. Akayesu" case the Chamber concluded that this "criminal intent is necessary also for command responsibility, but this is misleading, Command 
responsibility is not itself a crime, It is a form of individual criminal liability, a mode of participation in a crime that does not involve commission, presence, or even support for the crime" (Zahar, 2001). Finally, if the crimes committed were not widespread and were not backed by an organization or a system, it will be very difficult to prove the genocidal intent of an individual. The "intent to commit genocide" can be proven by objective legal standards with respect to decision makers and commanders. Thus, no one who writes in crimes against humanity and genocide can be accused in talking an issue simple or limited in scope, or of not expressing one's perception of "it is what it is." To be sure, many Words on the subject are not in short supply, to these Words, in awe or frustration, agreement or disagreement depending on which area of genocide intrigues us and whether it is agreeable to our own sense of reality (Garber, 2006).

\section{Conclusion}

The definition of the crime of genocide enumerates national, ethnical, racial, and religious groups as possible victim groups. However, when the Convention was adopted a source of great controversy continued to rage as whether or not enumerating of groups should be expanded, particularly to include political groups, gender groups and others. The article argued that, except when accomplished by mass killing, genocide does not necessarily mean the immediate destroy of a nation. The act of genocide may result in few victims, with respect to proving the necessary intent; the lack of evidence may render convection for genocide difficult to achieve. It is also not clear from the Convention whether a perpetrator must have had specific intent to destroy a particular group in whole or in part as such, beside a motive. The article explained that, at the present the case law of the Tribunals limited to the interpretation and application of Article (II) of the convention. It is true that, the international community utterly failed to prevent and stop genocide in Rwanda, Bosnia, and Iraq. So that, when efforts to prevent conflict fail, one of the highest priorities must be to protect civilians. Wherever civilians are deliberately targeted because they belong to a particular community, there is a risk of genocide. Thus, in order to prevent such massacre in the future, States parties obligations to be extended in the direction of a duty to intervene. The international community are still a long way away from reaching agreement about what kind of international intervention, particularly coercive military intervene in such circumstances, how and when and under whose authority the intervention should be undertaken, while the disagreement continues, people keep suffering and dying.

REFERENCES

\section{BOOKS}

1. A, Cassese, (2009), The Oxford Companion to
International Criminal Justice, New York : Oxford University Press.

2. A, Cassese, (2008), International Criminal Law. (2nd ed.) New York: Oxford University Press.

3. A, Zahar., and G, Sluiter, (2008), International Criminal Law : A critical Introduction. New York : Oxford University Press.

4. I, Bantekas. and S, Nash, (2007), International Criminal Law. (3th ed.) New York : RoutledgeCavendish.

5. L, Reydam, (2003), Universal Jurisdiction, International and Municipal Legal Perspective. New York : Oxford University Press.

6. M, Cherif Bassiouni, (1999), Crime against Humanity in International Law, (2nd ed.) The Hague/ London/ Bosto : Kluwer Law International.

7. M, Boot, (2002), Genocide, Crime against Humanity, War Crimes, Nullm Crimen Sine Lege and the Subject Matter Jurisdiction of the International Criminal Court. Antwerpen- Oxford-New York : Intersentia Publishers.

8. M, D. Evans, (2008), International Law. (2nd ed.) New York : Oxford University Press.

9. M, Inazumi, (2005), Universal Jurisdiction in Modern International Law, Expansion of National Jurisdiction for Prosecution Serious Crimes under International Law. Oxford : Intersentia Publisher.

10. R, Cryer. H, Friman. D, Robinson. and E, Wilmshurst, (2007), An Introduction to International Criminal Law and Procedure. New York : Cambridge University Press. 11.S, Macedo, (2004), Universal Jurisdiction, National Court and Prosecution of Serious Crimes Under International Law. Philadelphia : University of Pennsylvania Press.

12. W, A. Schabas, (2000), Genocide in International Law. New York: Cambridge University Press.

13. W, A. Schabas, (2009), Genocide in International Law, the Crime of Crimes. (2nd ed.) Cambridge University Press.

14. Nick, Grief, (2008), The War Crimes and International Criminal Law entries in Cane P and Conaghan J (eds.), The New Oxford Companion to Law, Oxford : OUP (2008),(pp. 604-605). and (pp. 1233-1234).

\section{JOURNAL ARTICLES AND CASES}

1. Alexander, Z. (2001), Command Responsibility of Civilian Superiors for Genocide. Leiden Journal of International Law 14, 591-616.

2. David, Hawk, (1987), Institute of the International Conference on the Holocaust and Genocide. Internet on the Holocaust and Genocide. Jerusalem 8, 6 .

3. Frank, C. (1989), Genocide in the 20th Century', Definition of Genocide and Their Implications for Prediction and Prevention. Holocaust Genocide Studies 4, 2, 149-160.

4. Harmen, van Wilt, (2006), Genocide, Complicity in Genocide and International v. Domestic Jurisdiction : 
Reflections on the van Anraat Case. Journal of International Criminal Justice, 4, 2, 1 239-257.

5. Kenneth, C. R. (1988), Universal Jurisdiction Under International Law. Texas Law Review 66, 785-807.

6. Nina, H.B. Jorgensen, (2002), The Genocide Acquittal in the Sikirica Case before the International Criminal Tribunal for the Former Yugoslavia and the Coming of Age of the Guilty Plea. Leiden Journal of International Law 15, 2, 389-407.

7. Otto, T. (2004), Genocide, and Its Particular Intent to Destroy in Whole or in Part the Group as Such. Leiden Journal of International Law 14, 2, 399-408.

8. Rytis, S. (2004), Soviet Genocide Trials in The Baltic States : The Relevance of International Law. Yearbook of International Humanitarian Law 7, 388-409.

9. William, A. S. (2007), Origins of the Genocide Convention : From Nuremberg to Paris. Case Western Reserve Journal of International Law 40, 1, 35-55.

10. William, R. Slomanson, (2008), Introductory Note to International Criminal Court; Summary of the Prosecutor's Application For Warrant of Arrest Agist Omar Hassan AlBahir.. American Society of International Law; Cambridge University Press 47, 829-832.

11. Xavier, P. (2006), The Principles of Universal Jurisdiction and Complementarily : How Do the Two Principles Intermesh? International Review of the Red Cross : Selected article on international humanitarian law 88,862 .

12. Zev, G. (2006), Judaic Studies. Shofar, Project Muses. An Interdisciplinary Journal of Jewish Studies 176.

13. Diane F. Orentlicher. (2009), Genocide, Crimes of War Project. Crimes of War Project. Retrieved from http://www.crimesofwar.org/thebook/genocide.h tml

14. Luc, Walleyn. (2003), The Sabra \& Shatila Massacre and the Belgian Universal Jurisdiction. Retrieved from http://programs.ssrc.org/gsc/publications/ICA_m emos/Panel3.Walleyn.doc

15. Prevent Genocide International. (2004), Retrieved from http :/ / www.preventgenocide.org/

16. Rome Statute of the International Criminal Court. Article 6 (genocide) (Adopted on 17 July 1998). Retrieved from http:/ / www.preventgenocide.org/ab/1998/

17. Genocide. (Adopted on 17 July 1998), Entry into force : 1 July 2002. List of ratifications and signatures for updated information, Retrieved from : www.icc-cpi.int or http :/ / www.iccnow.org

18. ICJ ( 8 April 1993), Advisory Opinions and Orders of the International Court of Justice. Retrieved from http://www.icj-cij.org/files/case-

related/91/7313.pdf

19. ICTY Prosecutor v Tihomir Blaskic, (29 October 1997), case IT-95-14-AR, 29. Retrieved from http://www.icty.org/x/cases/blaskic/acdec/en/7 1029JT3.html

20. ICTY Prosecutor v Krstic. Trial Chamber Judgment, (2 August 2001), paras 582-84. Retrieved from http://www.icty.org/x/cases/krstic/tjug/en/krstj010802e.pdf

21. Report of the International Commission of Inquiry on Darfur to the Secretary-General pursuant to Security Council Resolution 1564 (2004) of 18 September 2004, 1 February 2005, UN Doc S/205/60. Hereinafter; Darfur Report

22. The Prosecutor v. Goran Jelisic case, (IT-95-10-A), (2001), http ://www.icty.org/case/jelisic/4 